\title{
Differential proteome analysis of human embryonic kidney cell line (HEK-293) following mycophenolic acid treatment
}

\author{
Muhammad Qasim ${ }^{1,2}$, Hazir Rahman ${ }^{1,2}$, Michael Oellerich ${ }^{1}$ and Abdul R Asif ${ }^{{ }^{*}}$
}

\begin{abstract}
Background: Mycophenolic acid (MPA) is widely used as a post transplantation medicine to prevent acute organ rejection. In the present study we used proteomics approach to identify proteome alterations in human embryonic kidney cells (HEK-293) after treatment with therapeutic dose of MPA. Following 72 hours MPA treatment, total protein lysates were prepared, resolved by two dimensional gel electrophoresis and differentially expressed proteins were identified by QTOF-MS/MS analysis. Expressional regulations of selected proteins were further validated by real time PCR and Western blotting.

Results: The proliferation assay demonstrated that therapeutic MPA concentration causes a dose dependent inhibition of HEK-293 cell proliferation. A significant apoptosis was observed after MPA treatment, as revealed by caspase 3 activity. Proteome analysis showed a total of 12 protein spots exhibiting differential expression after incubation with MPA, of which 7 proteins (complement component $1 \mathrm{Q}$ subcomponent-binding protein, electron transfer flavoprotein subunit beta, cytochrome b-c1 complex subunit, peroxiredoxin 1, thioredoxin domaincontaining protein 12 , myosin regulatory light chain 2, and profilin 1) showed significant increase in their expression. The expression of 5 proteins (protein SET, stathmin, 40S ribosomal protein S12, histone H2B type 1 A, and histone $\mathrm{H} 2 \mathrm{~B}$ type $1-\mathrm{C} / \mathrm{E} / \mathrm{F} / \mathrm{G} / \mathrm{l})$ were down-regulated. MPA mainly altered the proteins associated with the cytoskeleton (26\%), chromatin structure/dynamics (17\%) and energy production/conversion (17\%). Both real time PCR and Western blotting confirmed the regulation of myosin regulatory light chain 2 and peroxiredoxin 1 by MPA treatment. Furthermore, HT-29 cells treated with MPA and total kidney cell lysate from MMF treated rats showed similar increased expression of myosin regulatory light chain 2.
\end{abstract}

Conclusion: The emerging use of MPA in diverse pathophysiological conditions demands in-depth studies to understand molecular basis of its therapeutic response. The present study identifies the myosin regulatory light chain 2 and peroxiredoxin 1 along with 10 other proteins showing significant regulation by MPA. Further characterization of these proteins may help to understand the diverse cellular effects of MPA in addition to its immunosuppressive activity.

Keywords: HEK-293 cells, proteome, mycophenolic acid, drug toxicology, differential proteomics

\section{Introduction}

Mycophenolic acid (MPA) is a frequently used immunosuppressant for the prevention of acute rejection in patients undergoing allogenic renal, cardiac, lung, and liver transplantations [1,2]. MPA is a selective, reversible

\footnotetext{
* Correspondence: asif@med.uni-goettingen.de

'Department of Clinical Chemistry, University Medical Centre Goettingen,

37075, Goettingen, Germany

Full list of author information is available at the end of the article
}

and uncompetitive inhibitor of inosine monophosphate dehydrogenase (IMPDH), a key regulatory enzyme in the de novo pathway of purine synthesis. It exhibits cytotoxic effects on most of the cell types, but exerts greater effects on $\mathrm{T}$ and $\mathrm{B}$ lymphocytes, thus preventing solid organ rejection [2]. IMPDH inhibition by clinically relevant concentration of MPA results in guanine nucleotide depletion which is associated with G1 cell cycle arrest. MPA also triggers apoptosis by up-
C Biomed Central 
regulating pro-apoptotic proteins (p53, p21 and bax) and down-regulating proteins that are important for cell cycle progression, such as bcl-2, survivin p27 and c-myc [3]. IMPDH type II is significantly over-expressed in several tumor cells, for this reason IMPDH could be considered as a potent target for anti-cancer therapy, as well as immunosuppressive chemotherapy [4].

MPA and its metabolites effect most of the cellular functions by influencing biological pathways, like apoptosis [5], immune associated signaling [6] and general cell signaling pathways involving mitogen-activated protein kinases, extracellular-signal regulated kinases, c-Jun $\mathrm{N}$-terminal kinases, $\mathrm{p} 53$ and Rho-associated protein kinase $[5,7,8]$. Collectively, MPA possesses anti-microbial, anti-inflammatory, anti-fibrotic, pro-apoptotic [2], anti-angiogenic, anti-cancerous [9] and anti-oxidant activities [10]. Due to MPA diverse therapeutic activities in the cell, it is also used for the treatment of dermatological diseases, neuromuscular diseases and autoimmune disorders such as lupus $[9,11]$. Gastrointestinal tract (GIT) complications i.e., diarrhoea, nausea, abdominal pain, vomiting, anorexia, gastritis, intestinal ulceration and small intestinal villous atrophy are common complication for some transplant patients on MPA therapy. Other MPA associated adverse effects are anemia, myelosuppression and risk of opportunistic infections [12]. The exact molecular mechanism of MPA organ toxicity is unknown, but possible mechanisms include direct toxicity by its anti-proliferative effect, opportunistic infections due to myelosuppression and toxicity, and acyl MPA glucuronide (AcMPAG) proteins adduct formation $[12,13]$.

Here we use HEK-293 cell line to uncover cellular protein response to the exposure of clinical dose of MPA. In the present study we used a proteomics based approach to resolve proteins of total cell lysates on two dimensional electrophoresis (2-DE) gels following treatment with DMSO and MPA. The differentially expressed proteins were in-gel tryptic digested and identified by QTOF-MS/MS analysis. Several proteins were identified with modified expression in response to MPA treatment which might be helpful to broaden our understanding regarding the cellular effects of MPA.

\section{Results}

In the present study the alteration in the cellular proteome by the MPA treatment was investigated using HEK-293 as cell culture model. Incubation of HEK-293 cells with MPA followed a dose dependent inhibition of cell proliferation (Figure 1). The $\mathrm{IC}_{50}$ concentration (7.5 $\mu \mathrm{mol} / \mathrm{L}$ or $2.4 \mathrm{mg} / \mathrm{L}$ ) of MPA was selected as standard dose for further analysis, which is within the therapeutic range $(0.3$ to $3.4 \mathrm{mg} / \mathrm{L})$ [14]. Cells were treated with MPA and DMSO (as vehicle) for 3 days, and total cell lysates were prepared. Total protein extracts of MPA and DMSO treated cells were separated by 2-DE using

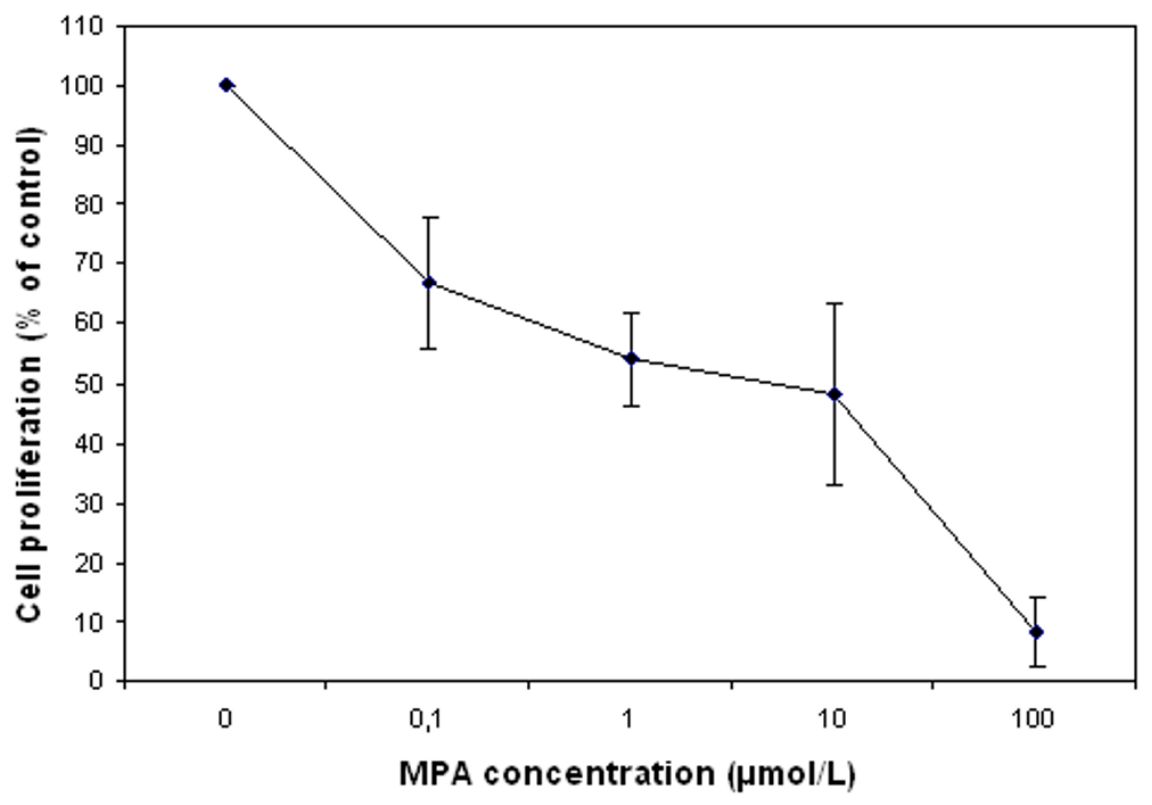

Figure 1 Inhibition of HEK-293 cells proliferation by MPA treatment. The cell proliferation was determined after $72 \mathrm{hr}$ of treatment with different doses of MPA (0-100 $\mu \mathrm{mol} / \mathrm{L})$ using BrdU colorimetric based method. Results are shown as percentage of control (DMSO treated) and represent four independent experiments. 
pH 3-10 linear IPG strips and visualized by silver stain. The protein spots which showed $\geq \pm 1.5$ fold change ( $\mathrm{p}$ $<0.05$ using Student's t test) as compared to DMSO treated controls were considered as differentially expressed proteins. Statistical analysis showed that a total of 12 proteins exhibited significantly altered expression due to MPA treatment (Table 1). The altered expression pattern of the HEK-293 proteins by MPA is shown in Figure 2. Among 12 regulated proteins spot under MPA treatment, 7 proteins were significantly upregulated and 5 proteins showed down-regulated expression. The up-regulated spots under MPA treatment were identified as complement component $1 \mathrm{Q}$ subcomponent binding protein $(\mathrm{C} 1 \mathrm{q})$, electron transfer flavoprotein subunit beta, cytochrome b-c1 complex subunit, thioredoxin domain-containing protein 12 , myosin regulatory light chain 2 (MLC2), peroxiredoxin1 (Prdx1) and profilin 1. Five proteins, which showed down-regulated expression, were identified as protein SET, stathmin, $40 \mathrm{~S}$ ribosomal protein $\mathrm{S} 12$, histone $\mathrm{H} 2 \mathrm{~B}$ type 1-A, and histone $\mathrm{H} 2 \mathrm{~B}$ type $1-\mathrm{C} / \mathrm{E} / \mathrm{F} / \mathrm{G} / \mathrm{I}$. A bar diagram, showing relative abundance $(\% \mathrm{Vol}), \mathrm{SD}$ and statistical significance of all the significantly regulated protein is provided as "Additional file 1 figure s1". Figure 2 shows an exemplary gel of DMSO (vehicle) and MPA with marked regulated proteins. The extent of regulation in protein expression with predicted and actual pI, as well as molecular masses with their Swiss Prot accession numbers are provided in Table 1 and MS/MS spectral information is provided in the "Additional file 2 table s1". Functional classification of differentially regulated proteins was done using KOGnitor, an online biological function annotation tool [15]. The proteins altered by MPA treatment belong to various categories i.e., cytoskeleton (26\%), chromatin structure/dynamics and energy production/conversion (17\% each) (Figure 3). Gels spot diagram of two selected protein spots (MLC2 and Prdx1) in 4 biological replicates are shown in Figure 4a. To validate the 2-DE results, the expression of MLC2 and Prdx1 were confirmed by Western blotting and real time PCR analysis. Expression of Prdx1 and MLC2 were up-regulated at both transcriptional (Figure 4b) and protein level (Figure 4c). Specifically, MPA increased MLC2 protein (Mean fold: $+1.78, \mathrm{p}<0.005, \mathrm{n}=4$, Western blotting) and mRNA expression (Mean fold: $+2.25, \mathrm{p}<$ $0.05, \mathrm{n}=4$, real time PCR). Prdx1 expression was also up-regulated, both at protein level (Mean fold: +2.73 , p $<0.005, \mathrm{n}=4$ ) and mRNA level (Mean fold: +1.93 , $\mathrm{p}<$ $0.05, \mathrm{n}=4)$. To check whether over-expression of MLC2 following MPA treatment is only HEK-293 cells specific, we determined MLC2 expression in total protein lysate prepared from kidney of MMF (pro-drug of

Table 1 Differentially regulated proteins by MPA in HEK-293 cells identified by mass spectrometry

\begin{tabular}{|c|c|c|c|c|c|c|c|c|}
\hline $\begin{array}{l}\text { Spot } \\
\text { No }\end{array}$ & Acc & $\begin{array}{l}\mathrm{M}_{\mathrm{t}} / \mathrm{M}_{\mathrm{o}} \\
(\mathrm{kDa})\end{array}$ & Score & $\mathrm{pl}_{\mathrm{t}} / \mathrm{pl}_{\mathrm{o}}$ & Pep & Protein name & FunctionBy KOGnitor NCBI & $\begin{array}{l}\text { Expression } \\
\text { change (in } \\
\text { folds) }\end{array}$ \\
\hline 6 & Q01105 & $33.4 / 37.0$ & 154 & $4.23 / 4.14$ & 3 & Protein SET & $\begin{array}{c}\text { Replication, recombination and } \\
\text { repair }\end{array}$ & $1.86^{*} \downarrow$ \\
\hline 9 & Q07021 & $31.3 / 31.0$ & 141 & $4.74 / 4.5$ & 3 & $\begin{array}{l}\text { Complement component } 1 \mathrm{Q} \\
\text { subcomponent-binding protein, } \\
\text { mitochondrial }\end{array}$ & Defense mechanisms & $1.58^{*} \uparrow$ \\
\hline 14 & P38117 & $27.8 / 25.5$ & 181 & $8.24 / 9.18$ & 6 & Electron transfer flavoprotein subunit beta & $\begin{array}{l}\text { Energy production and } \\
\text { conversion }\end{array}$ & $1.54^{*} \uparrow$ \\
\hline 15 & P47985 & $29.6 / 25.0$ & 112 & $8.51 / 7.081$ & 6 & $\begin{array}{c}\text { Cytochrome b-c1 complex subunit Rieske, } \\
\text { mitochondrial }\end{array}$ & $\begin{array}{l}\text { Energy production and } \\
\text { conversion }\end{array}$ & $3.71^{* *} \uparrow$ \\
\hline 18 & Q06830 & $22.0 / 21.0$ & 64 & 8. $27 / 8.14$ & 2 & Peroxiredoxin-1 & $\begin{array}{l}\text { Posttranslational modification, } \\
\text { protein turnover, chaperones }\end{array}$ & $1.71^{* *} \uparrow$ \\
\hline 22 & P16949 & $17.2 / 15.8$ & 56 & $5.76 / 6.32$ & 3 & Stathmin & General function prediction only & $1.50^{* *} \downarrow$ \\
\hline 23 & 095881 & $19.1 / 16.0$ & 123 & $5.24 / 5.89$ & 4 & $\begin{array}{l}\text { Thioredoxin domain-containing protein } \\
\qquad 12\end{array}$ & Cytoskeleton & $1.95^{*} \uparrow$ \\
\hline 24 & 014950 & $19.7 / 16.0$ & 195 & $4.71 / 5.32$ & 4 & Myosin regulatory light chain MRLC2 & Cytoskeleton & $3.41^{*} \uparrow$ \\
\hline 27 & Q96A08 & $14.1 / 14.5$ & 51 & $10.31 / 7.0$ & 2 & Histone $\mathrm{H} 2 \mathrm{~B}$ type $1-\mathrm{A}$ & $\begin{array}{l}\text { Chromatin structure and } \\
\text { dynamics }\end{array}$ & $1.90^{*} \downarrow$ \\
\hline 28 & P62807 & $13.8 / 14.2$ & 250 & $10.31 / 6.51$ & 9 & Histone H2B type 1-C/E/F/G/l & $\begin{array}{l}\text { Chromatin structure and } \\
\text { dynamics }\end{array}$ & $1.58^{*} \downarrow$ \\
\hline 31 & P25398 & $14.5 / 13.0$ & 89 & $6.81 / 7.10$ & 3 & 40 S ribosomal protein S12 & $\begin{array}{l}\text { Translation, ribosomal structure } \\
\text { and biogenesis }\end{array}$ & $2.44^{*} \downarrow$ \\
\hline 34 & P07737 & $15.0 / 13.5$ & 142 & $8.44 / 9.07$ & 6 & Profilin-1 & Cytoskeleton & $1.51^{* *} \uparrow$ \\
\hline
\end{tabular}

Acc: Accession number; Mt: theoretical molecular mass; Mo: observed molecular mass; plt: theoretical isoelectric point; plo: observed isoelectric point; pep: number of peptides sequenced for identification; Score: Peptide mass fingerprint probability score as defined by Mascot (www.matrixscience.com). Individual ions score $>42$ indicate identity or extensive homology $(p<0.05)$; $\downarrow$ : down-regulated; $\uparrow$ up-regulated; ${ }^{*} p<0.05$, ${ }^{* *} p<0.005$. Molecular function determined from the online protein reference database KOGnitor NCBI (http://www.ncbi.nlm.nih.gov/COG/grace/kognitor.html). 

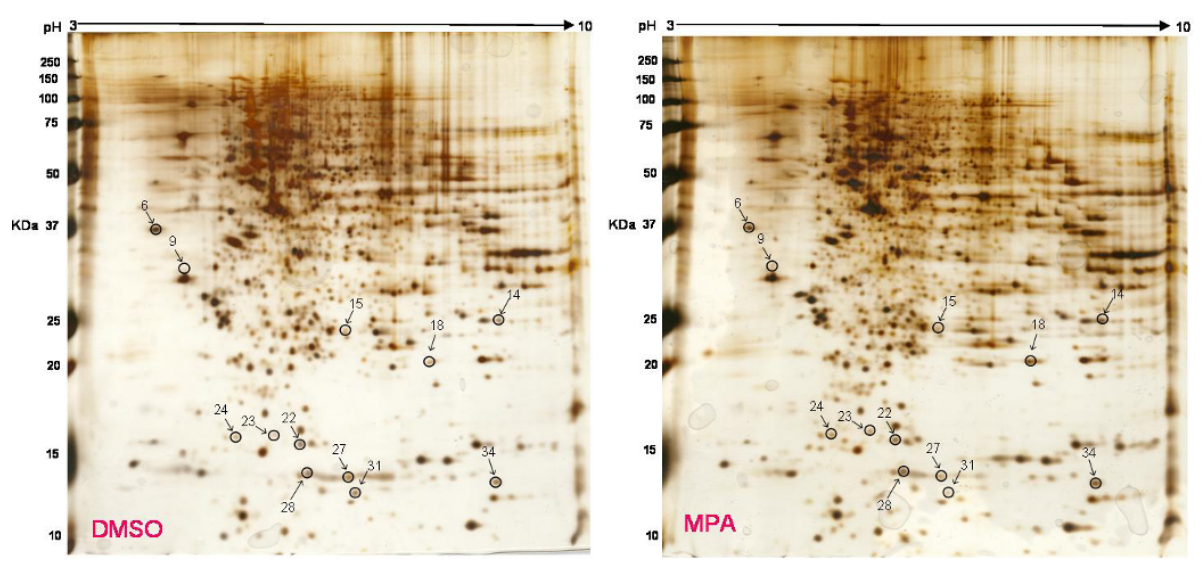

Figure 2 Differential protein expression after incubation of HEK-293 cells with MPA. Total protein lysate from DMSO and MPA treated cells was separated by 2-D gel electrophoresis and silver stained. Encircled differentially regulated proteins spots were identified using Q-TOF MS/MS analysis. The figure shows exemplary 2-DE gels of DMSO and MPA treated HEK-293 cells.

MPA) treated rats (Figure 5a) and MPA treated HT-29 cells (Figure 5b). MLC2 expression was increased both in kidney total protein lysate and HT-29 cells by (Mean fold: $+2.57, \mathrm{p}<0.005, \mathrm{n}=4$ ) and (Mean fold: $+1.95, \mathrm{p}<$ $0.005, \mathrm{n}=4$ ) respectively.

To demonstrate the effect of MPA on cell apoptosis, caspase-3 activity (apoptosis marker) was determined using a commercially available colorimetric assay. There was a significant difference in caspase-3 activity between MPA and DMSO treatment groups. MPA increased mean absorbance by 2 fold ( $\mathrm{p}<0.005, \mathrm{n}=5$ ) as compared to DMSO treated cells. The results from caspase- 3 assay revealed that MPA treated cells exhibit more apoptosis than cells treated with DMSO alone (Figure 6).

\section{Discussion}

We have used a 2-DE and mass spectrometric based proteomics approach to develop a better understanding of the influence of MPA therapeutic dose on the proteome in HEK-293 cells. HEK-293 cells are widely used

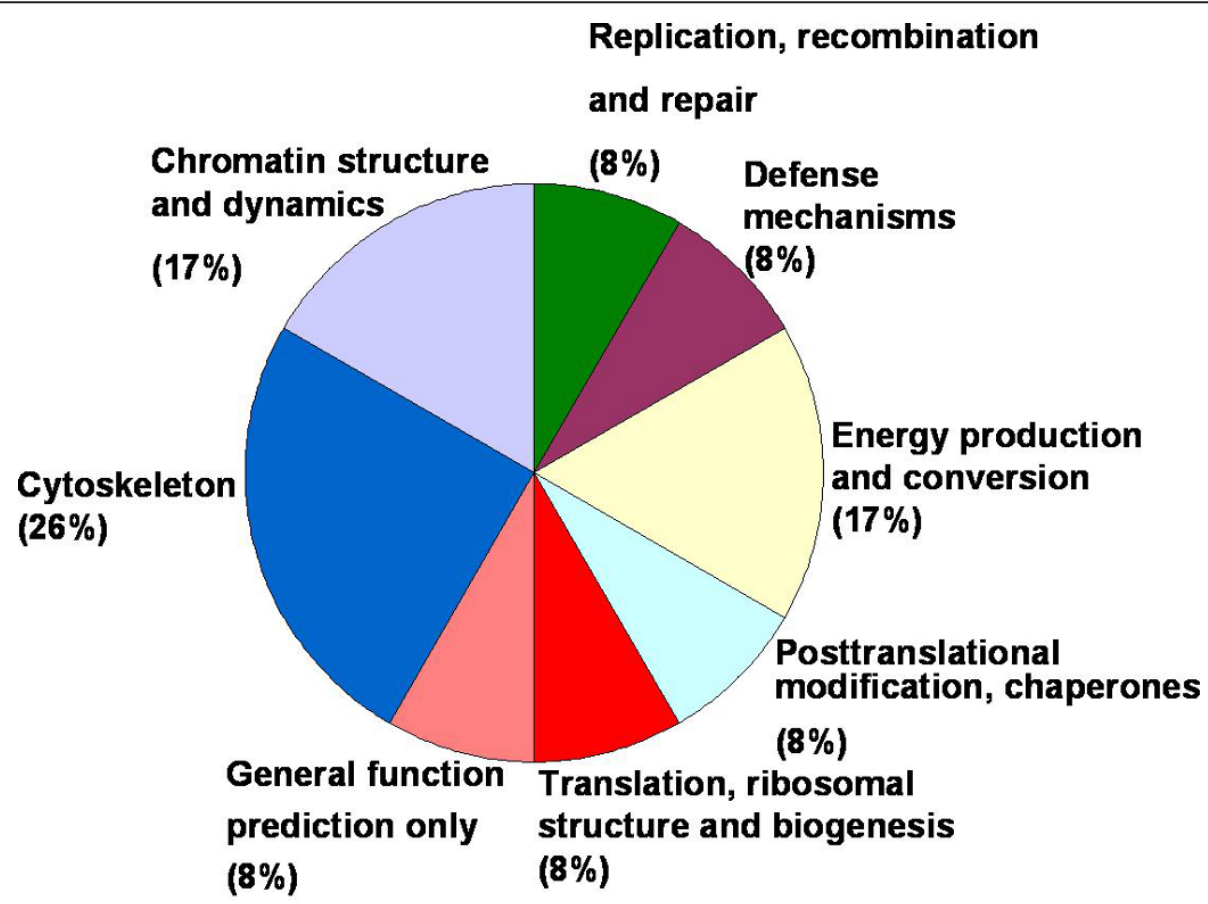

Figure 3 Functional classification of regulated proteins. Biological functions were assigned using online KOGnitor NCBI (http://www.ncbi.nlm. nih.gov/COG/grace/kognitor.html) software. 


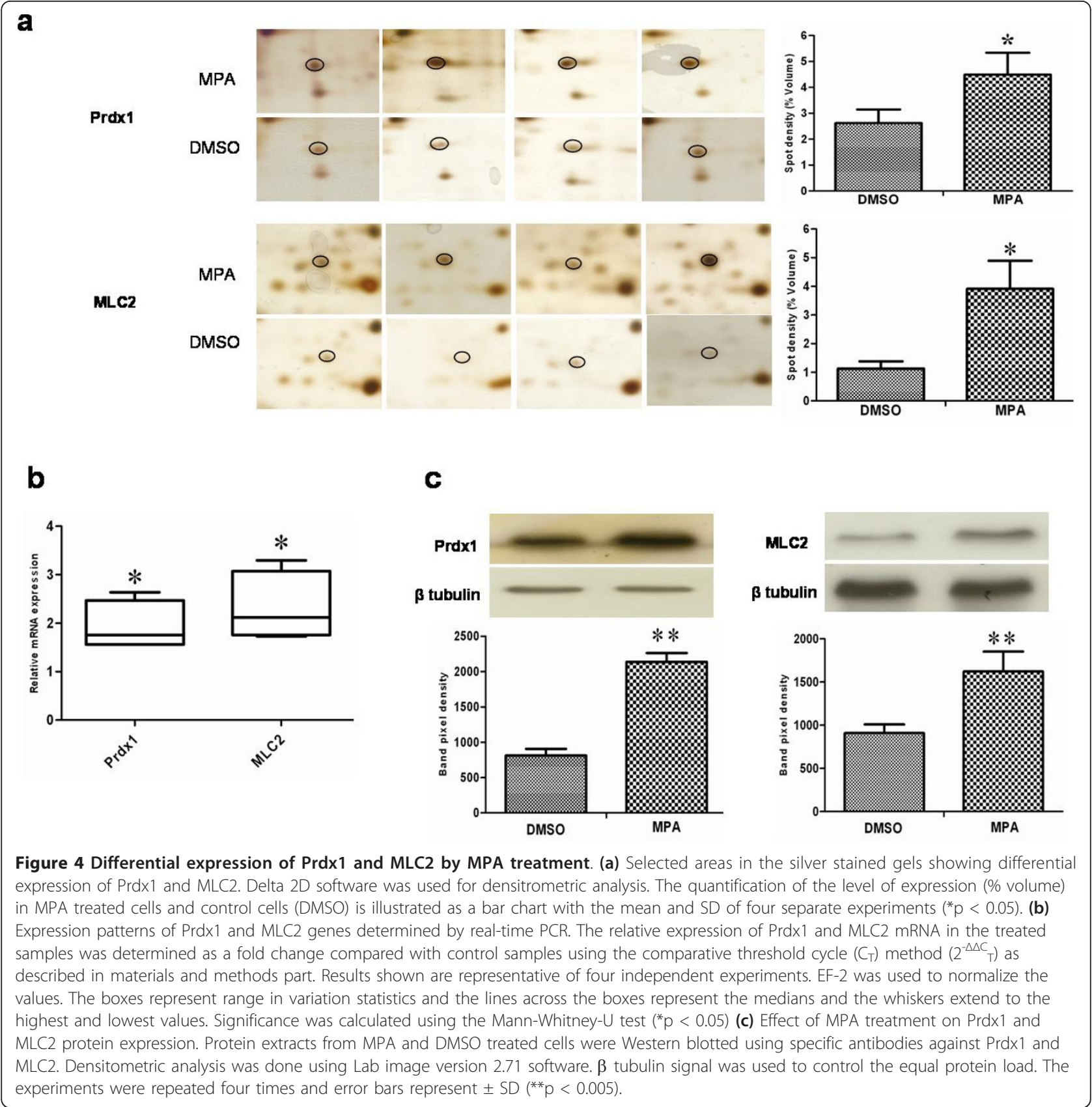

cell culture model to study the mechanisms of drug action, investigating drug targets and molecular aspects of xenobiotic toxicity [16-18]. The regulated proteins are found to be involved in diverse functions including apoptosis and cell signaling mechanism. Apoptosis assay showed that MPA has a pro-apoptotic role in HEK-293 cell line, a property which makes it a drug with potential anti-tumor activities. MLC2 is an important myosin regulatory subunit, which regulates smooth muscle and nonmuscle cells contractile activity [19]. MLC2 displayed an increased expression by MPA treatment. It is already reported that MPA influences the cellular cytoskeletal architecture via modulating mesangial actin reorganization by activating actin polymerization and inhibiting actin-depolymerization [20,21]. Phosphorylation of MLC2 causes significant changes in the physiological dynamics of actin cytoskeleton, leading to barrier defects in intestine [22], heart [23] and lungs [24]. However, it remains unclear if such cytoskeleton reorganization in different organs may lead to a completely different outcome, for example in intestine, diarrhoea is associated with MPA therapy in some patients [12]. In 


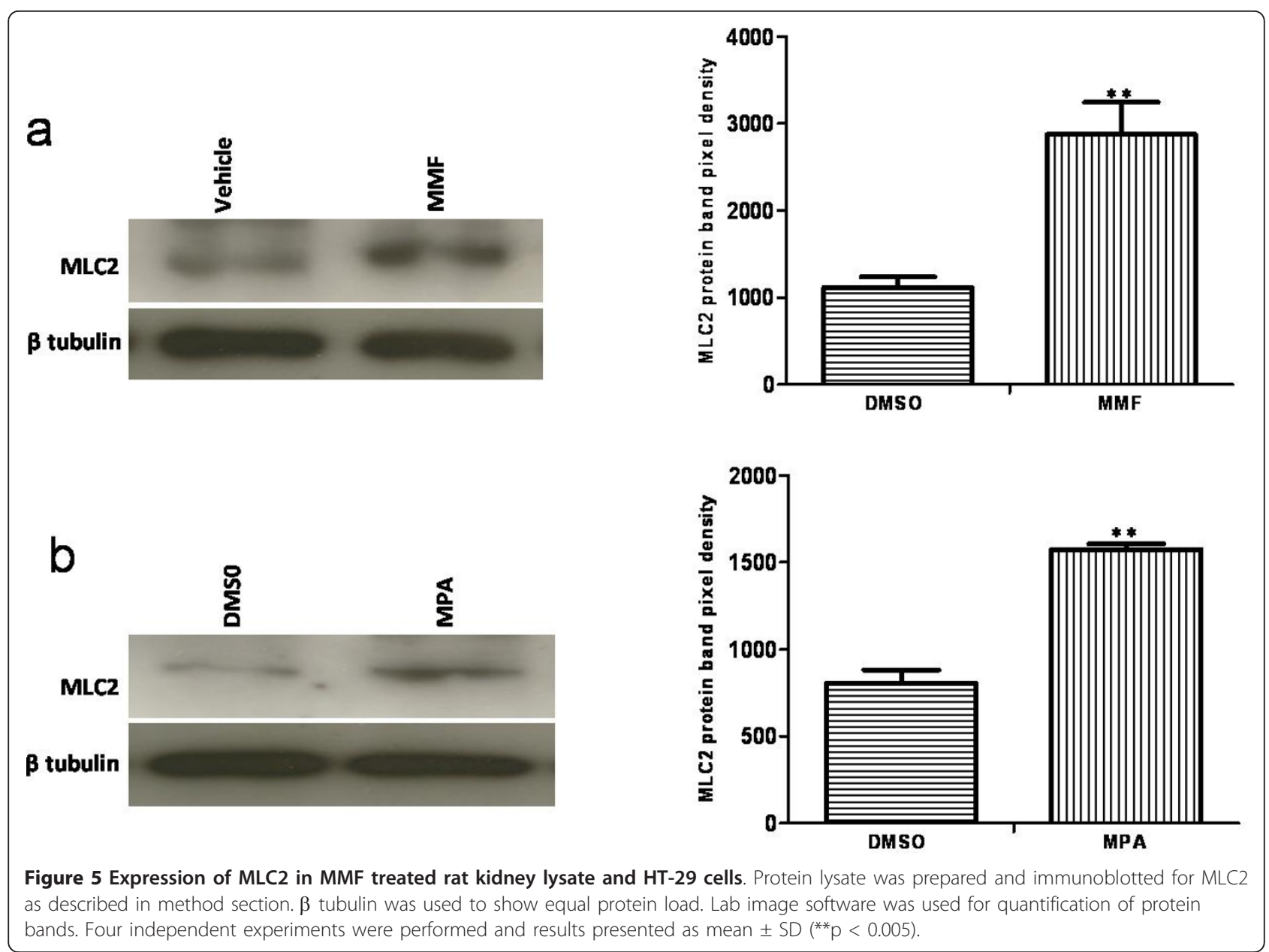

the present study, we observed that MLC2 over-expression is not limited to a specific cell type (i.e. HEK-293) but was reproducible in MMF treated rat kidney and in MPA treated HT-29 cells protein lysates.
We observed an increase Prdx1 expression by MPA treatment, both at gene and protein level.. Prdx1 is a cytoplasmic stress-inducible anti-oxidant enzyme and a major member of peroxiredoxin family [25]. Cells

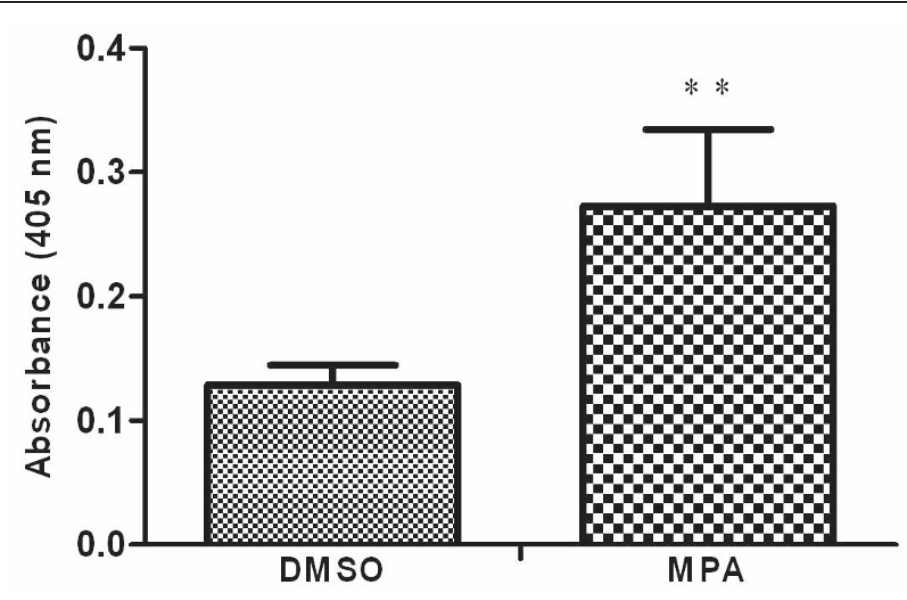

Figure 6 Measurement of MPA induced caspase-3 activity. Cells were treated with MPA and DMSO for 72 h. Protein extracts from each was measured for caspase-3 activity. Five independent experiments were performed and results presented as mean absorbance \pm SD (** $p<0.005)$. 
deficient in Prdx1 have increased sensitivity to oxidative DNA damage [26]. Prdx1 along with its anti-oxidant activity also possesses anti-inflammatory and antiatherogenic effects [27]. Oxidative stress contributes to the pathophysiology of diverse clinical conditions, including ischemia-reperfusion mediated post transplantation graft injuries [28]. Prdx1 expression was also reported to be up-regulated in human gingival fibroblasts by cyclosporine A (another commonly used immunosuppressive drug) treatment [29]. MPA has previously been reported to diminish oxidative injuries and induce anti-oxidant effects by preventing the production of reactive oxygen species [10]. Furthermore, MPA exerts lesser oxidative stress in renal transplant patients, as compared to everolimus, cyclosporine and other calcineurin inhibitors [30,31] 30,31. Prdx1 contribute to the inhibition of tumorigenesis through PTEN/Akt pathway [32] and its lower expression in the tumor indicated high tumor proliferation, increased metastasis and could be used as cancer biomarker [33]. Prdx1 is also involved in ageing process as Prdx1-deficient mice have a shortened lifespan and other malignancies [26]. Anti-tumor drugs like histone deacetylase inhibitors (HDACIs) activate Prdx1, a tumor suppressor, which leads to apoptosis [34]. Previously it was observed that MPA also inhibit histone deacetylases (HDACs) [35]. A further investigation is needed to gain a deeper insight into the Prdx1 regulation by MPA through HDACs inhibition interaction with Prdx1 and its role in anti-tumor activities.

Profilin 1, another cytoskeletal protein was up-regulated by MPA treatment. Profilins are widely distributed actin binding proteins [36], involved in actin filament dynamics and several signaling pathways [37]. Profilin 1 over-expression has been reported to cause cell proliferation inhibition, apoptosis induction and tumor suppression [38]. Whether MPA via profilin overexpression exerts extended anti-proliferative or antitumor activities requires further investigation. Stathmin was down regulated by MPA. Stathmin is a $19 \mathrm{kDa}$ cytoplasmic protein, which plays an important role in the regulation of the microtubule cytoskeleton. Stathmin regulates microtubule turnover by promoting microtubules depolymerization and hydrolyze guanosine triphosphate (GTP) from terminal tubulin, preventing polymerization of tubulin heterodimers [39]. Previously, our group demonstrated that AcMPAG alters tubulin polymerization in a concentration-dependent manner [40]. Furthermore, stathmin repression stabilizes microtubules, inhibits angiogenesis [41] and suppress tumors [42].

Thioredoxin domain-containing protein 12 , also known as endoplasmic reticulum resident protein 18 (ERp18) is ubiquitous in mammalian cells and acts as a disulfide isomerase in the endoplasmic reticulum (ER). It provides defense against oxidative stress, refolds disulfide-containing proteins, and regulates transcription factors [43]. ERp18 expressional up-regulation might cause cell adoptivity in response to MPA induced ER stress. SET protein was down-expressed by MPA. SET, a major cellular serine threonine phosphatase is a potent inhibitor of protein phosphatase 2A (PP2A) activity [44] and a negative regulator of histone acetylation [45], thus involved in cell growth and signaling cascades [46]. PP2A expression induced by down-regulation of SET leads to the apoptosis and growth suppression [47],

MPA triggers nuclear stress and causes disruption of the nucleus, leading to the activation of $\mathrm{p} 53$, which may initiate cell cycle arrest and apoptosis [48]. In the present study histone $\mathrm{H} 2 \mathrm{~B}$ was down-regulated by MPA treatment, which is a major component of eukaryotic nucleosome core. Post translational modification such as methylation, acetylation, phosphorylation and ubiquitination of histone proteins alter transcription, DNA replication, and DNA repair $[49,50]$. Previous data showed that MPA mediated down-regulation of HDAC2 which might relate with potential epigenetic regulations [35]. The microrarray analysis of mononuclear cells treated with AcMPAG (a metabolite of MPA) showed down-regulation of histones in a previous study by our group [51].

MPA affects ribosomal machinery by decreasing intracellular guanine nucleotide level, depending on dosage and cell type, resulting in global reduction of RNA synthesis [48]. Other studies suggested that guanine nucleotide depletion by IMPDH leads to a decrease in pre-ribosomal RNA synthesis, nuclear disruption, and p53 activation [52]. Disorganization of nuclear and ribosomal biogenesis is suggested to be an effective therapeutic target in cancers [53]. We observed a downregulation of $40 \mathrm{~S}$ ribosomal protein $\mathrm{S} 12$ by MPA, which might be due to the altered ribosome biogenesis. The proapoptotic stimuli including chemotherapeutic agents induced a dose-dependent increase in the expression of the cytochrome c proteins [54]. In the present study we also observed up-regulation of cytochrome b-c I complex by MPA which suggests a possible role of MPA in the regulation of energy metabolism. Complement component $1 \mathrm{Q}$ subcomponent-binding protein (C1q), a component of complement system involved in the clearance of apoptotic cells was up-regulated by MPA. C1q binds to surface blebs of apoptotic cells, which follows subsequent phagocytosis [55]. C1q deficiency leads to a significant decline in the clearance of apoptotic cells in both $\mathrm{C} 1 \mathrm{q}$ - and C4-deficient mice, causing glomerulonephritis [56]. MPA causes cellular apoptosis and cells might utilize $\mathrm{C} 1 \mathrm{q}$ over-expression to clear the apoptotic cells. 


\section{Conclusion}

This investigation identifies proteins related to diverse cellular functions which altered their expression by MPA treatment; many of which are reported for the first time in this context. The expression of Prdx1 (involved in apoptosis) and MLC2 (protein important for epithelial barrier integrity) were observed to be regulated at RNA and protein level. Further investigations of the regulated proteins will provide new insights into the cellular pathways influenced by MPA therapy and could help in more rational use of MPA in transplantation medicine.

\section{Methods \\ Reagents}

Cell culture media (DMEM and MacCoy's), fetal calf serum (FCS), phosphate buffer saline (PBS), penicillin and streptomycin were purchased from PAA Laboratories, Colbe, Germany. Urea, thiourea, dithiothreitol (DTT), trypsin, triflouroacetic acid (TFA), sodium carbonate, ammonium bicarbonate, MPA and DMSO were purchased from Sigma-Aldrich, Steiheim, Germany. Acetonitril (ACN) was obtained from Promochem, Wasel, Germany. CHAPS was obtained from AppliChem, Darmstadt, Germany. Ampholytes, protein assay kit and immobilised $\mathrm{pH}$ gradient strips (IPG strips) were procured from Bio-Rad, Munich, Germany, while protease and phosphatase inhibitor cocktails were purchased from Roche, Mannheim, Germany. Bromophenol blue and trizma base were obtained from Carl Roth, Karlsruhe, Germany. Sodium dodecyl sulfate (SDS) was obtained from Serva, Heidelberg, Germany. Glycerin, potassium ferricynaide and sodium thiosulfate were purchased from Merck, Darmstadt, Germany and formic acid from BASF, Ludwigshafen, Germany.

\section{Cell culturing}

HEK-293 and HT-29 cell lines were purchased from German collection of microorganisms and cell cultures (DSMZ), Braunschweig, Germany. The cells were grown in $75 \mathrm{~cm}^{2}$ culture flasks (Sarstedt, Nuemberecht, Germany) and maintained in culture at $37^{\circ} \mathrm{C}$ in $95 \%$ humidity, $20 \% \mathrm{O}_{2}$ and $5 \% \mathrm{CO}_{2}$. DMEM and MacCoy's media supplemented with L-glutamine, $10 \%$ fetal calf serum, $100 \mathrm{U} / \mathrm{mL}$ penicillin, and $0.1 \mathrm{mg} / \mathrm{mL}$ streptomycin was used to grow HEK-293 and HT-29 cells respectively.

\section{Proliferation assay}

Briefly, cells were grown in 96 well plates at a density of $3.5 \times 10^{4}$ cells/well at least $24 \mathrm{~h}$ prior to the start of the experiment. The cells were then incubated with DMSO (control) or 0 to $100 \mu \mathrm{mol} / \mathrm{L}$ MPA for a period of $72 \mathrm{~h}$. After completion of incubation, proliferation was determined using ELISA based BrdU cell assay (Roche
Diagnostics) according to manufacturer's recommendations. Four independent experiments were performed. $\mathrm{IC}_{50}$ values were calculated by a Grafit software package, version 5 (Erithacus Software, London, UK).

\section{Sample preparation for proteome analysis}

The HEK-293 and HT-29 cells were grown for $24 \mathrm{~h}$ followed by treatment with DMSO or MPA $(7.5 \mu \mathrm{mol} / \mathrm{L}$ and $10 \mu \mathrm{mol} / \mathrm{L}$ for HEK-293 and HT-29 respectively) for $72 \mathrm{~h}$. Cells were harvested by scraping and were washed three times with ice cold PBS. After washing, cells were pelleted down at $250 \times \mathrm{g}$ for $10 \mathrm{~min}$ and lysed in a buffer containing $7 \mathrm{~mol} / \mathrm{L}$ urea, $2 \mathrm{~mol} / \mathrm{L}$ thiourea, $4 \% \mathrm{w} / \mathrm{v}$ CHAPS, $2 \%$ ampholyte $\mathrm{pH} 3-10$ and $1 \%$ DTT. The lysates were centrifuged and protein content was measured by Bradford assay [57] using Bio-Rad protein reagent (Bio-Rad, Munich, Germany) according to manufacturer's instructions. Sample aliquots were kept at $-80^{\circ} \mathrm{C}$ until further use. Protein lysate was prepared from 21 days MMF treated adult female Wistar rat's kidney according to the previously reported protocol [58] and were used for Westernblotting.

\section{2-DE}

The 2-DE was performed as described by Gorg et al 2000 [59] with some minor modifications. Protein samples of HEK-293 cell $(110 \mu \mathrm{g})$ were mixed with rehydration buffer $(7 \mathrm{~mol} / \mathrm{L}$ urea, $2 \mathrm{~mol} / \mathrm{L}$ thiourea, $4 \%$ CHAPS, $0.2 \%$ ampholyte [pH 3-10], and $0.2 \%$ DTT) containing trace amount of bromophenol blue to a total volume of $350 \mu \mathrm{L}$. Samples were applied to linear IPG strips [pH 3-10], Bio- Rad) for $1 \mathrm{~h}$ and then covered with mineral oil for passive rehydration overnight at room temperature. Iso-electric focusing (IEF) was performed in Protean IEF cell (Bio-Rad) with a program of $1 \mathrm{~h}$ at 100 volts, $1 \mathrm{~h}$ at 500 volts, $2 \mathrm{~h}$ at 1000 volts and 8000 volts with a total of 32000 volts-h. For the second dimension electrophoretic separation, focused strips were equilibrated for $30 \mathrm{~min}$ at room temperature in a buffer containing $50 \mathrm{mmol} / \mathrm{L}$ Tris-HCL [pH 8.8], $6 \mathrm{~mol} / \mathrm{L}$ urea, $30 \% \mathrm{v} / \mathrm{v}$ glycerol, $2 \%$ SDS and $10 \mathrm{~g} / \mathrm{L}$ DTT followed by an identical incubation but replacing DTT with $40 \mathrm{~g} / \mathrm{L}$ iodoacetamide. The proteins in the equilibrated strips were then resolved on the $12.5 \%$ SDS-PAGE in a Protean II chamber (Bio-Rad) at $100 \mathrm{~V} / 4^{\circ} \mathrm{C}$.

\section{Protein visualization, densitometric analysis and in-gel digestion}

Gels were silver stained as described by Blum et al 1987 [60]. After fixation, gels were washed and sensitized. The gels were then incubated in freshly prepared silver nitrate solution $(0.2 \%$ silver nitrate and $0.026 \%$ formaldehyde) for $20 \mathrm{~min}$ at room temperature followed by 3 times washes of $20 \mathrm{sec}$ each in distilled water. Gels were 
placed in developing solution (6\% sodium carbonate, $0.018526 \%$ formaldehyde and $6 \%$ sodium thiosulfate) until standard marker stained completely and adequate spots were visualized. Gels were scanned with a gel Cano scan 8400 (Canon, Tokyo, Japan). Densitrometric analysis was done by using Delta 2D software version 3.6 (Decodon GmbH, Gerifswald, Germany) [61]. Spot intensities were first normalized and the relative intensity of each spot was calculated by dividing the intensity of each spot by the sum of all spots intensities on the corresponding gel. Fold change, SD and Student's t test probability were calculated using Microsoft excel software. Spots having at least 1.5 fold expressional changes $(\mathrm{p}<0.05)$ were considered statistically significant. Four independent 2-DE experiments were performed. Differentially regulated protein spots were excised from the silver stained gel with a clean scalpel blade followed by in-gel digestion according to the method adopted and modified from Shevchenko et al [62]. Briefly, the gel pieces were washed twice in $100 \mathrm{mmol} / \mathrm{L}$ ammonium bicarbonate/acetonitrile $(1: 1, \mathrm{v} / \mathrm{v})$ initially for $10 \mathrm{~min}$ and then until all visible dye was removed. The gel pieces were dried using vacuum centrifuge (UNIVAPO $150 \mathrm{H}$; uniEquip, Matinsried, Germany) followed by reconstitution in the trypsin digestion solution (10 ng/ $\mu \mathrm{L}$ in $100 \mathrm{mmol} / \mathrm{L}$ ammonium bicarbonate) overnight at $37^{\circ} \mathrm{C}$. After incubation the supernatant containing digested peptides was transferred to a tube and $50 \mu \mathrm{L}$ of $0.1 \%$ TFA was added followed by sonication for $30 \mathrm{~min}$. After sonication, the supernatant was pooled with the previous one. Two further extractions were collected in the same way using $0.1 \%$ TFA in $30 \%$ and then $60 \%$ ACN. The pooled extracts of peptides were dried in vacuum centrifuge and reconstituted in $0.1 \%$ formic acid.

\section{Q-TOF LC-MS/MS analysis of protein identification}

The reconstituted peptide samples $(1 \mu \mathrm{L})$ were introduced onto $\mu$-precolumn ${ }^{\mathrm{TM}}$ cartridge (C18 pepMap; 300 $\mu \mathrm{m} \times 5 \mathrm{~mm} ; 5 \mu \mathrm{m}$ particle size) and further separated through a C18 pepMap 100 nano- $\operatorname{Series}^{\mathrm{TM}}(75 \mu \mathrm{m} \times 15$ $\mathrm{cm} ; 3 \mu \mathrm{m}$ particle size) analytical column (LC Packings, Germering, Germany) using an CapLC autosampler (Waters, Eschborn, Germany). The mobile phase consisted of solution A $(0.1 \%$ formic acid prepared in $5 \%$ ACN) and solution B (0.1\% formic acid prepared in $95 \%$ $\mathrm{ACN})$. The sample run time was set to $60 \mathrm{~min}$ and the flow rate of the pump to $5 \mu \mathrm{L} / \mathrm{min}$. The exponential gradient was initiated at $5 \mathrm{~min}$ after loading from $10 \%$ to $95 \%$ for the period of $50 \mathrm{~min}$. Tip flow rate of 250 $\mathrm{nL} / \mathrm{min}$ was achieved through a flow splitter. The eluted peptides were injected into a Q-TOF Ultima Global (Micromass, Manchester, UK) mass spectrometer equipped with a nanoflow ESI Z-spray source in positive ion mode. Data was acquired by MassLynx (v 4.0) software and peak list (pkl file) was generated from acquired MS/MS raw data using ProteinLynx Global Server bioinformatics tool (PLGS; v 2.2; Waters, Manchester, U.K.) under the following settings; Electrospray, centroid 80\% with minimum peak width 4 channel, noise reduction $10 \%$, Savitzky-Golay, MSMS, medium deisotoping with $3 \%$ threshold, no noise reduction and no smoothing. The generated pkl files were searched using the online MASCOT (http://www.matrixscience.com) algorithm against the SwissProt data base release 15.5 (515203 sequence entries, 181334896 elements). The search criteria was set as follows: enzyme, trypsin; allowance of up to one missed cleavage peptide; mass tolerance \pm 0.5 $\mathrm{Da}$ and MS/MS tolerance $\pm 0.5 \mathrm{Da}$; modifications of cysteine carboamidomethylation and methionine oxidation. Proteins were finally identified on the basis of two or more peptides, whose ion scores exceeded the threshold, $P<0.05$, which indicated the 95\% confidence level for these matched peptides. To ensure accurate identification, protein spots were digested from more than two gels and analyzed with MS. Proteins were considered as identified if the threshold was exceeded and the protein spot possessed the correct molecular weight and pI value of the corresponding spot on 2-DE.

\section{Functional classification}

Biological function annotations for all of the identified proteins were done by KOGnitor (http://www.ncbi.nlm. nih.gov/COG/grace/kognitor.html) [15].

\section{Western blotting}

Proteins were separated on $12.5 \%$ SDS-PAGE and blotted onto PVDF membrane (ImmobilonP, Millipore) using semidry Trans-Blot ${ }^{\circledR}$ SD cell system (Bio-Rad, Munich, Germany) for $30 \mathrm{~min}$ at $15 \mathrm{~V}$ in a blotting buffer $(192 \mathrm{mmol} / \mathrm{L}$ glycine, $20 \%$ methanol, $25 \mathrm{mmol} / \mathrm{L}$ Tris, pH 8.3). The membranes were blocked with $5 \%$ $(\mathrm{w} / \mathrm{v})$ skimmed milk repared in TBS-T buffer $(50 \mathrm{mmol} /$ L Tris- $\mathrm{HCl}$ [pH 7.5], $200 \mathrm{mmol} / \mathrm{L} \mathrm{NaCl}, 0.05 \%$ Tween 20) for $1 \mathrm{~h}$ at room temperature and washed twice with TBS-T buffer. The membranes were incubated with 1:1000 mouse anti Prdx1 antibody (Abcam, Cambridge, MA), 1:1000 rabbit anti MLC2 (Cell Signaling Technology, Inc., Danvers, MA) and 1:1000 mouse anti beta tubulin (Biovender, Czech Republic) overnight at $4{ }^{\circ} \mathrm{C}$, followed by washes with TBS-T buffer. Membranes were further incubated with appropriate HRP-conjugated secondary antibodies for $1 \mathrm{~h}$ at room temperature. The signals on the blots were detected by using ECL system (GE Healthcare) according to manufacturer's instructions. Signal intensities from each Western blot were quantified by using Lab Image software, version 2.71 (Leipzig, Germany). $\beta$ tubulin was used as a loading 
control and at least four independent experiments were performed.

\section{RNA isolation and CDNA synthesis}

RNA was extracted using Trizol reagent (Invitrogen, Carlsbad, CA) according to manufacturer's recommendations. Briefly, cells were scraped, washed and then homogenized in Trizol reagent. RNA was separated by chloroform/isopropanol precipitation method. The concentration of RNA was determined by the GeneQuant II RNA/DNA calculator (Pharmacia Biotech, Freiburg, Germany). The RNA quality was verified at $\mathrm{OD}_{260} /$ $\mathrm{OD}_{280} \mathrm{~nm}$ ratios and subsequent electrophoretically on $1 \%$ agarose gels using ethidium bromide staining. The cDNAs were synthesized from $2 \mu \mathrm{g}$ total RNA in a 30 $\mu \mathrm{L}$ reaction mix containing $1 \times$ reverse transcriptase (RT) PCR buffer (10 mmol/L Tris-HCL [pH 8.3], 15 $\mathrm{mmol} / \mathrm{L} \mathrm{KCl}, 0.6 \mathrm{mmol} / \mathrm{L} \mathrm{MgCl}_{2}$ ), $0.5 \mathrm{mmol} / \mathrm{L}$ of dNTPs mix, $1 \mathrm{U} / \mu \mathrm{L}$ RNase inhibitor and $13.3 \mathrm{U} / \mu \mathrm{L} \mathrm{M}$ MLV RT enzyme. The RT reaction was performed in a thermocycler (Biometra, Goettingen, Germany) at $42^{\circ} \mathrm{C}$ for $1 \mathrm{~h}$. cDNA was stored at $-70^{\circ} \mathrm{C}$ until use.

\section{Real-time PCR}

Relative quantitative PCR were carried out using the LightCycler instrument (Roche Diagnostic Systems, NJ, USA). The primers for the human Prdx1 (forward 5'TGGGGTCTTAAAGGCTGATG-3' and reverse 5'TCCCCATGTTTGTCAGTGAA -3'), human MLC2 (forward 5' - CAGGAGTTCAAAGAGGCCTTCAAC -3' and reverse 5'- CTGTACAGCTCATCCACTTCCTCA -3 ') and elongation factor 2 (forward 5'-GACATCACCAAGGGTGTGCAG-3' and reverse 5'-GCGGTCAGCACACTGGCATA-3) were designed by the Primer3 software (http://frodo.wi.mit.edu) [63]. The total volume of $20 \mu \mathrm{L}$ PCR contained $1 \mu \mathrm{L}$ of cDNA solution, $2 \mu \mathrm{L}$ of $10 \times$ PCR buffer (Invitrogen), $2 \mu \mathrm{L}$ Syber green, $1 \mu \mathrm{L}$ BSA, $1 \mu \mathrm{L}$ DMSO, $0.25 \mu \mathrm{L}$ of each primer (Eurofins MWG-Biotech, Ebersberg, Germany), $2.0 \mathrm{mmol} / \mathrm{L}$ $\mathrm{MgCl}_{2}, 0.2 \mathrm{mmol} / \mathrm{L} \mathrm{dNTPs}$ mix and $0.15 \mathrm{U} / \mu \mathrm{L}$ PAN Script DNA polymerase (PAN Biotech, Aidenbach, Germany). The amplification conditions for $\operatorname{Prdx} 1$ and MLC2 were: initial denaturation $30 \mathrm{sec}$ at $95^{\circ} \mathrm{C}$ and repeated cycles of denaturation $\left(95^{\circ} \mathrm{C}\right.$ for $\left.1 \mathrm{sec}\right)$, primer annealing $\left(55^{\circ} \mathrm{C}\right.$ for $\left.5 \mathrm{sec}\right)$, elongation $\left(72^{\circ} \mathrm{C}\right.$ for $\left.10 \mathrm{sec}\right)$, and fluorescence reading at $82^{\circ} \mathrm{C}$. For elongation factor 2 (EF-2) PCR conditions were similar to Prdx1 except for primer fluorescence reading which was measured at $88^{\circ} \mathrm{C}$. The relative expression of $\operatorname{Prdx} 1$ and MLC2 mRNA in the treated samples was determined as a fold increase compared with control samples using the comparative threshold cycle $\left(C_{\mathrm{T}}\right)$ method $2^{-\Delta \Delta} \mathrm{C}_{\mathrm{T}}\left(\Delta \Delta C_{\mathrm{T}}=\right.$ $\Delta C$ target genes $-\Delta C$ reference gene) [64]. EF-2 was used as the internal control gene. Experiments were performed four times. Statistical difference ( $\mathrm{p}$ value) in mRNA expression level between MPA and DMSO samples were calculated using the Mann-Whitney U test. The PCR product was run on a $1 \%$ ethidium bromideagarose gel to confirm the presence of desired specific amplified product.

\section{Apoptosis assay}

The caspase 3 activity was measured using CaspACE ${ }^{\mathrm{TM}}$ Assay kit (Promega Corporation, WI, USA) according to the manufacturer's protocol. Cells were treated with DMSO and MPA for $72 \mathrm{~h}$, harvested and briefly suspended in lysis buffer. Proteins were extracted and quantified by Bradford method [57]. Briefly, $70 \mu \mathrm{g}$ of protein lysate were mixed with reaction mixtures containing colorimetric substrate peptides specific for caspase 3 (DEVD-pNA) and then incubated at room temperature for overnight. The absorbance of the cleaved $p$-nitroanilide from the substrate DEVD- $p$ NA was measured at $405 \mathrm{~nm}$ using EL808 microplate reader (Bio-Tek instruments, VT, USA). Five independent experiments were performed.

\section{Additional material}

Additional file 1: A graphical representation of relative abundance (\% volume) of all differentially regulated proteins. Relative abundance of the proteins differentially expressed in DMSO and MPA treated HEK-293 cells. Results shown as mean of four independent experiments $\left({ }^{*} \mathrm{p}<0.05\right.$ or $\left.{ }^{* *} \mathrm{p}<0.005\right)$.

Additional file 2: MS/MS analysis table of all differentially regulated proteins. Accession number, sequence coverage, score and MS/MS spectra of identified proteins.

\section{Acknowledgements}

We are grateful to Christina Wiese, Christa Scholz and Susanne Goldmann for expert technical assistance. Authors are indebted to the kind advice of Victor Armstrong (deceased in 2010). This work was supported by the grant from the University Medical Center, University of Goettingen. Muhammad Qasim and Hazir Rahman positions were supported by Human Resource Development Program of Kohat University of Science and Technology, Kohat and HEC, Pakistan. We are very obliged to Vicky C. Maixner for critical reading of the manuscript.

\section{Author details}

1Department of Clinical Chemistry, University Medical Centre Goettingen, 37075, Goettingen, Germany. ${ }^{2}$ Department of Microbiology, Kohat University of Science and Technology, 26000, Kohat, Pakistan.

\section{Authors' contributions}

MQ carried out the experiments and drafted the manuscript. HR contributed to the data analysis. ARA and MO participated in the design, supervision and interpretation of the study. All authors have read and approved the final manuscript.

\section{Competing interests}

The authors declare that they have no competing interests.

Received: 13 May 2011 Accepted: 20 September 2011

Published: 20 September 2011 


\section{References}

1. van Hest RM, van GT, Vulto AG, Mathot RA: Population pharmacokinetics of mycophenolic acid in renal transplant recipients. Clin Pharmacokinet 2005, 44:1083-1096.

2. Allison AC, Eugui EM: Mycophenolate mofetil and its mechanisms of action. Immunopharmacology 2000, 47:85-118.

3. Messina E, Gazzaniga P, Micheli V, Guaglianone MR, Barbato S, Morrone S, et al: Guanine nucleotide depletion triggers cell cycle arrest and apoptosis in human neuroblastoma cell lines. Int J Cancer 2004, 108:812-817.

4. Nagai M, Natsumeda Y, Konno Y, Hoffman R, Irino S, Weber G: Selective up-regulation of type II inosine 5'-monophosphate dehydrogenase messenger RNA expression in human leukemias. Cancer Res 1991, 51:3886-3890

5. Park YJ, Ahn HJ, Chang HK, Kim JY, Huh KH, Kim MS, et al: The RhoGDIalpha/JNK signaling pathway plays a significant role in mycophenolic acid-induced apoptosis in an insulin-secreting cell line. Cell Signal 2009, 21:356-364.

6. von VS, Ouyang H, Ley K: Mycophenolic acid suppresses granulopoiesis by inhibition of interleukin-17 production. Kidney Int 2010, 79-88.

7. Ha H, Kim MS, Park J, Huh JY, Huh KH, Ahn HJ, et al: Mycophenolic acid inhibits mesangial cell activation through p38 MAPK inhibition. Life Sci 2006, 79:1561-1567.

8. Heller T, Asif AR, Petrova DT, Doncheva Y, Wieland E, Oellerich M, et al: Differential proteomic analysis of lymphocytes treated with mycophenolic acid reveals caspase 3-induced cleavage of rho GDP dissociation inhibitor 2. Ther Drug Monit 2009, 31:211-217.

9. Villarroel MC, Hidalgo M, Jimeno A: Mycophenolate mofetil: An update. Drugs Today (Barc) 2009, 45:521-532.

10. Van den Branden C, Ceyssens B, Pauwels M, Van WG, Heirman I, Jie N, et al: Effect of mycophenolate mofetil on glomerulosclerosis and renal oxidative stress in rats. Nephron Exp Nephrol 2003, 95:e93-e99.

11. Stassen PM, Kallenberg CG, Stegeman CA: Use of mycophenolic acid in non-transplant renal diseases. Nephrol Dial Transplant 2007, 22:1013-1019.

12. Shipkova M, Armstrong WW, Oellerich M, Wieland E: Mycophenolate mofetil in organ transplantation: focus on metabolism, safety and tolerability. Expert Opin Drug Metab Toxicol 2005, 1:505-526.

13. Shipkova M, Armstrong WW, Oellerich M, Wieland E: Acyl glucuronide drug metabolites: toxicological and analytical implications. Ther Drug Monit 2003, 25:1-16

14. Hubner Gl, Eismann R, Sziegoleit W: Relationship between mycophenolate mofetil side effects and mycophenolic acid plasma trough levels in renal transplant patients. Arzneimittelforschung 2000, 50:936-940.

15. Tatusov RL, Fedorova ND, Jackson JD, Jacobs AR, Kiryutin B, Koonin EV, et al: The COG database: an updated version includes eukaryotes. BMC Bioinformatics 2003, 4:41.

16. Prat $O$, Berenguer F, Malard V, Tavan E, Sage N, Steinmetz G, et al: Transcriptomic and proteomic responses of human renal HEK293 cells to uranium toxicity. Proteomics 2005, 5:297-306.

17. MacDonald ML, Lamerdin J, Owens S, Keon BH, Bilter GK, Shang Z, et al: Identifying off-target effects and hidden phenotypes of drugs in human cells. Nat Chem Biol 2006, 2:329-337.

18. Sohn SH, Ko E, Jo Y, Kim SH, Kim Y, Shin M, et al: The genome-wide expression profile of Paeonia suffruticosa-treated cisplatin-stimulated HEK 293 cells. Environ Toxicol Pharmacol 2009, 28:453-458.

19. Suizu F, Ueda K, Iwasaki T, Murata-Hori M, Hosoya H: Activation of ActionActivated MgATPase Activity of Myosin II by Phyosphorylation with MAPK-Activated Protein Kinase-1b (RSK-2). Journal of Biochemistry 2000, 128:435-440

20. Mondin M, Moreau V, Genot E, Combe C, Ripoche J, Dubus I: Alterations in cytoskeletal protein expression by mycophenolic acid in human mesangial cells requires Rac inactivation. Biochem Pharmacol 2007, 73:1491-1498.

21. Dubus I, L'Azou B, Gordien M, Delmas Y, Labouyrie JP, Bonnet J, et al: Cytoskeletal reorganization by mycophenolic acid alters mesangial cell migration and contractility. Hypertension 2003, 42:956-961.

22. Shen L, Black ED, Witkowski ED, Lencer WI, Guerriero V, Schneeberger EE, et al: Myosin light chain phosphorylation regulates barrier function by remodeling tight junction structure. J Cell Sci 2006, 119:2095-2106.

23. Yuan SY, Wu MH, Ustinova EE, Guo M, Tinsley JH, De LP, et al: Myosin light chain phosphorylation in neutrophil-stimulated coronary microvascular leakage. Circ Res 2002, 90:1214-1221.
24. Zhao Y, Rhoades RA, Packer CS: Hypoxia-induced pulmonary arterial contraction appears to be dependent on myosin light chain phosphorylation. Am J Physiol 1996, 271:L768-L774.

25. Ishii T, Yanagawa T: Stress-induced peroxiredoxins. Subcell Biochem 2007, 44:375-384.

26. Neumann CA, Krause DS, Carman CV, Das S, Dubey DP, Abraham JL, et al: Essential role for the peroxiredoxin Prdx1 in erythrocyte antioxidant defence and tumour suppression. Nature 2003, 424:561-565.

27. Mowbray AL, Kang DH, Rhee SG, Kang SW, Jo H: Laminar shear stress upregulates peroxiredoxins (PRX) in endothelial cells: PRX 1 as a mechanosensitive antioxidant. J Biol Chem 2008, 283:1622-1627.

28. Schreibelt $G$, van HJ, Haseloff RF, Reijerkerk A, van der Pol SM, Nieuwenhuizen $O$, et al: Protective effects of peroxiredoxin- 1 at the injured blood-brain barrier. Free Radic Biol Med 2008, 45:256-264

29. Jung JY, Kang GC, Jeong YJ, Kim SH, Kwak YG, Kim WJ: Proteomic analysis in cyclosporin A-induced overgrowth of human gingival fibroblasts. Biol Pharm Bull 2009, 32:1480-1485.

30. de CM, Silva S, Cruz D, Basso F, Corradi V, Lentini $P$, et al: Oxidative stress and 'monocyte reprogramming' after kidney transplant: a longitudinal study. Blood Purif 2008, 26:105-110.

31. Land W, Vincenti F: Toxicity-sparing protocols using mycophenolate mofetil in renal transplantation. Transplantation 2005, 80:S221-S234.

32. Cao J, Schulte J, Knight A, Leslie NR, Zagozdzon A, Bronson R, et al: Prdx1 inhibits tumorigenesis via regulating PTEN/AKT activity. EMBO J 2009, 28:1505-1517.

33. Yanagawa T, Iwasa $S$, Ishii T, Tabuchi $K$, Yusa H, Onizawa $K$, et al: Peroxiredoxin I expression in oral cancer: a potential new tumor marker. Cancer Lett 2000, 156:27-35.

34. Hoshino I, Matsubara H, Hanari N, Mori M, Nishimori T, Yoneyama $Y$, et al: Histone deacetylase Inhibitor FK228 activates tumor suppressor Prdx1 with apoptosis induction in esophageal cancer cells. Clin Cancer Res 2011, 11:7945-7952.

35. Domhan S, Muschal S, Schwager C, Morath C, Wirkner U, Ansorge W, et al: Molecular mechanisms of the antiangiogenic and antitumor effects of mycophenolic acid. Mol Cancer Ther 2008, 7:1656-1668.

36. Rawe VY, Payne C, Schatten G: Profilin and actin-related proteins regulate microfilament dynamics during early mammalian embryogenesis. Hum Reprod 2006, 21:1143-1153.

37. Das T, Bae YH, Wells A, Roy P: Profilin-1 overexpression upregulates PTEN and suppresses AKT activation in breast cancer cells. J Cell Physiol 2009, 218:436-443.

38. Zou L, Ding Z, Roy P: Profilin-1 overexpression inhibits proliferation of MDA-MB-231 breast cancer cells partly through p27kip1 upregulation. J Cell Physiol 2010, 223:623-629.

39. Rubin $\mathrm{Cl}$, Atweh GF: The role of stathmin in the regulation of the cell cycle. J Cell Biochem 2004, 93:242-250.

40. Feichtiger $H$, Wieland $E$, Armstrong WW, Shipkova M: The acyl glucuronide metabolite of mycophenolic acid induces tubulin polymerization in vitro. Clin Biochem 2010, 43:208-213.

41. Miyashita $H$, Kanemura $M$, Yamazaki T, Abe M, Sato Y: Vascular endothelial zinc finger 1 is involved in the regulation of angiogenesis: possible contribution of stathmin/OP18 as a downstream target gene. Arterioscler Thromb Vasc Biol 2004, 24:878-884.

42. Alli $E$, Yang $J M$, Hait WN: Silencing of stathmin induces tumor-suppressor function in breast cancer cell lines harboring mutant p53. Oncogene 2007, 26:1003-1012

43. Liu F, Rong YP, Zeng LC, Zhang X, Han ZG: Isolation and characterization of a novel human thioredoxin-like gene hTLP19 encoding a secretory protein. Gene 2003, 315:71-78.

44. Trotta R, Ciarlariello D, Dal CJ, Allard J, Neviani P, Santhanam R, et al: The PP2A inhibitor SET regulates natural killer cell IFN-gamma production. J Exp Med 2007, 204:2397-2405

45. Seo SB, McNamara P, Heo S, Turner A, Lane WS, Chakravarti D: Regulation of histone acetylation and transcription by INHAT, a human cellular complex containing the set oncoprotein. Cell 2001, 104:119-130.

46. Sontag E: Protein phosphatase 2A: the Trojan Horse of cellular signaling. Cell Signal 2001, 13:7-16.

47. Neviani P, Santhanam R, Trotta R, Notari M, Blaser BW, Liu S, et al: The tumor suppressor PP2A is functionally inactivated in blast crisis CML through the inhibitory activity of the BCR/ABL-regulated SET protein. Cancer Cell 2005, 8:355-368. 
48. Sun XX, Dai MS, Lu H: Mycophenolic acid activation of $\mathrm{p} 53$ requires ribosomal proteins L5 and L11. J Biol Chem 2008, 283:12387-12392.

49. Wu D, Ingram A, Lahti JH, Mazza B, Grenet J, Kapoor A, et al: Apoptotic release of histones from nucleosomes. J Biol Chem 2002, 277:12001-12008,

50. Spencer VA, Davie JR: Role of covalent modifications of histones in regulating gene expression. Gene 1999, 240:1-12.

51. Petrova DT, Heller T, Hitt R, Wieland E, Oellerich M, Armstrong WW, et af: Regulation of IL2 and NUCB1 in mononuclear cells treated with acyl glucuronide of mycophenolic acid reveals effects independent of inosine monophosphate dehydrogenase inhibition. Ther Drug Monit 2009, 31:31-41.

52. Huang M, Ji Y, Itahana K, Zhang Y, Mitchell B: Guanine nucleotide depletion inhibits pre-ribosomal RNA synthesis and causes nucleolar disruption. Leuk Res 2008, 32:131-141.

53. Yoshioka N, Wang L, Kishimoto K, Tsuji T, Hu GF: A therapeutic target for prostate cancer based on angiogenin-stimulated angiogenesis and cancer cell proliferation. Proc Natl Acad Sci USA 2006, 103:14519-14524.

54. Sanchez-Alcazar JA, Khodjakov A, Schneider E: Anticancer drugs induce increased mitochondrial cytochrome $\mathrm{c}$ expression that precedes cell death. Cancer Res 2001, 61:1038-1044.

55. Taylor PR, Carugati A, Fadok VA, Cook HT, Andrews M, Carroll MC, et al: A hierarchical role for classical pathway complement proteins in the clearance of apoptotic cells in vivo. J Exp Med 2000, 192:359-366.

56. Botto M, Dell'Agnola C, Bygrave AE, Thompson EM, Cook HT, Petry F, et al: Homozygous $\mathrm{C1q}$ deficiency causes glomerulonephritis associated with multiple apoptotic bodies. Nat Genet 1998, 19:56-59.

57. Bradford MM: A rapid and sensitive method for the quantitation of microgram quantities of protein utilizing the principle of protein-dye binding. Anal Biochem 1976, 72:248-254.

58. Asif AR, Armstrong WW, Voland A, Wieland E, Oellerich M, Shipkova M: Proteins identified as targets of the acyl glucuronide metabolite of mycophenolic acid in kidney tissue from mycophenolate mofetil treated rats. Biochimie 2007, 89:393-402.

59. Gorg A, Obermaier C, Boguth G, Harder A, Scheibe B, Wildgruber R, et al: The current state of two-dimensional electrophoresis with immobilized pH gradients. Electrophoresis 2000, 21:1037-1053.

60. blum H, Beier H, Gross HJ: Improved silver staining of plant proteins, RNA and DNA in polyacrylamide gels. Electrophoresis 1987, 8:93-99.

61. Luhn S, Berth M, Hecker M, Bernhardt J: Using standard positions and image fusion to create proteome maps from collections of twodimensional gel electrophoresis images. Proteomics 2003, 3:1117-1127.

62. Shevchenko A, Wilm M, Vorm O, Mann M: Mass spectrometric sequencing of proteins silver-stained polyacrylamide gels. Anal Chem 1996, 68:850-858.

63. Rozen S, Skaletsky H: Primer3 on the WWW for general users and for biologist programmers. Methods Mol Biol 2000, 132:365-386.

64. Schmittgen TD, Livak KJ: Analyzing real-time PCR data by the comparative C(T) method. Nat Protoc 2008, 3:1101-1108.

doi:10.1186/1477-5956-9-57

Cite this article as: Qasim et al:: Differential proteome analysis of human embryonic kidney cell line (HEK-293) following mycophenolic acid treatment. Proteome Science 2011 9:57.

\section{Submit your next manuscript to BioMed Central and take full advantage of:}

- Convenient online submission

- Thorough peer review

- No space constraints or color figure charges

- Immediate publication on acceptance

- Inclusion in PubMed, CAS, Scopus and Google Scholar

- Research which is freely available for redistribution

Submit your manuscript at www.biomedcentral.com/submit
Biomed Central 